\title{
Model Struktural Kompetensi Industri 4.0 dengan Social Intelligence sebagai Variabel Intervening
}

\author{
Dewi Comala Sari \\ Politeknik Negeri Medan, Medan \\ Heru Pranoto \\ Politeknik Negeri Medan, Medan \\ Edi Putra Berutu \\ Politeknik Negeri Medan, Medan \\ Edy Sahputra Sitepu \\ Politeknik Negeri Medan, Medan \\ Email: dewicomalasari@polmed.ac.id
}

\begin{abstract}
Abstrak
Penelitian ini mengalisis model struktural bagaimana variabel new media literacy, cross cultural competency, adaptive thinking, virtual collaboration dan social intelligence mempengaruhi kesiapan sumber daya manusia dari perguruan tinggi untuk memasuki industri 4.0. Penelitian dilakukan di perguruan tinggi vokasi yang ada di Kota Medan, dimana sampel ditetapkan dengan purposive random sampling sebanyak 400 responden. Dalam analisis ini dilakukan dengan dengan model struktural dimana variabel social intelligence menjadi variabel intervening untuk kesiapan memasuki industri 4.0. Output penelitian ini diharapkan untuk memberikan masukan dan strategi bagi perguruan tinggi vokasi dalam melakukan penguatan kualitas SDM yang dihasilkan untuk memasuki pasar tenaga kerja. Berdasarkan hasil analisis data full model SEM duperoleh bahwa new media literacy, virtual collaboration, adaptive thinking dan cross cultural competency berpengaruh positif dan signifikan terdahap variabel social intelligence. Sedangkan untuk variabel kesiapan di industri 4.0 secara positif dan signifikan dipengaruhi oleh variabel adaptive thinking, new media literacy, dan cross cultural competency. Sedangkan pengaruh variabel virtual collaboration adalah positif namun tidak signifikan. Untuk peran mediasi dapat disimpulkan bahwa variabel social intelligence memiliki peran partial mediation effect untuk variabel new media literacy dan adaptive thinking. Sedangkan untuk variabel virtual collaboration dan cross cultural competency variabel social intelligence memberikan peran full mediation effect.
\end{abstract}

Kata Kunci: Industry 4.0, social intelligent, adaptive thinking, cross-cultural competency, new-media literacy, virtual collaboration.

\section{Pendahuluan}

Dewasa ini revolusi industri 4.0 telah menjadi paradigma baru yang sedang menjadi pembahasan hangat di dunia, tidak terkecuali di Indonesia. Blanchet et al. (2014) mengemukakan bahwa revolusi industri 4.0 merupakan perkembangan yang terkati dengan kekuatan manufaktur industri yang dioptimalkan dengan teknologi internet mutakhir yang menjadi inti gerkanan perkembangan industri 4.0. Oleh karena itu wajar bila industri 4.0 mengalami perhatian yang semakin meningkat terutama di Eropa (Blanchet et al., 2014) termasuk di Indonesia (Nurwardani, 2018), demikian pula di Amerika Serikat dimana telah 
berkembang industrial internet (Annunziata \& Evans, 2012). Industri 4.0 kerap dikaitkan dengan transformasi industri yang ditandai dengan hadirnya mesin uap, listrik dan lain-lain. Mirip dengan Industri 4.0 "revolusi" ini dimulai bukan oleh teknologi tunggal, tetapi oleh interaksi jumlah kemajuan teknologi yang efek kuantitatifnya menciptakan cara-cara produksi yang baru.

Teknologi pabrikasi baru selalu menjadi keunggulan kompetitif bagi perusahaan karena teknologi ini membantu produksi lebih cepat dan lebih fleksibel, dimana kemajuan pesat di teknologi manufaktur juga telah berkontribusi pada pengembangan industri. Industri 4.0 merupakan terminologi konsep realistis revolusi industri berikutnya. Visi terpenting dari revolusi industri ke-4 ini adalah munculnya pabrik-pabrik pintar. Di pabrik pintar, sensor, mesin, dan sistem TI akan terhubung ke sistem cyber-physical - CPS (Benesova et al., 2018).

Blok bangunan Industri 4.0 adalah sembilan teknologi dasar - robot otonom, internet of things (IoT), big data, simulasi, integrasi sistem vertikan maupun horizontal, komputasi awan, keamanan siber, keamanan dunia maya, manufaktur aditif, dan augmented reality. Sembilan tren teknologi ini akan mengubah produksi menjadi aliran produksi yang sepenuhnya terintegrasi, otomatis, dan dioptimalkan. Manufaktur cerdas akan membantu mencapai proses manufaktur yang fleksibel, cerdas, dan dapat dikonfigurasi ulang untuk ditangani pasar yang dinamis. Revolusi industri ini tidak hanya berdampak pada industri tetapi juga pada pasar tenaga kerja dan pendidikan. Beberapa profesi dan pekerjaan menghilang. Alasan utama dampak ini adalah perubahan persyaratan pendidikan pada karyawan. Mengontrol, memelihara, dan mengoperasikan teknologi baru hanya akan membutuhkan karyawan yang berkualitas (Benesova et al., 2018; Rüßmann et al., 2015).

Seiring dengan dikekenalnya Industri 4.0 juga diperkenalkan Education 4.0, yakni sebutan untuk konsep pendidikan di era digital baru. Tren teknologi baru seperti augmented reality akan diimplementasikan ke sistem pendidikan. Sistem pendidikan baru ini akan menggabungkan informasi dunia nyata dan virtual (Quint et al, 2015). Diharapkan bahwa ketersediaan jumlah SDM handal akan meningkat di bidang studi teknis. Karena setiap perusahaan akan membutuhkan karyawan dengan pendidikan teknis. Untuk alasan ini, kaum muda harus dididik dalam bidang-bidang seperti robotika, sibernetika, analisis data, dan ilmu teknis atau ilmu alam lainnya. Lulusan masa depan harus dididik inline dengan Industri 4.0. Ini bermasalah, karena tidak jelas bagaimana inovasi akan berkembang dan kualifikasi dan pengetahuan apa yang dibutuhkan lulusan masa depan untuk profesi mereka di Industri 4.0.

Kerjasama antara sekolah dan universitas dengan perusahaan menjadi sangat penting untuk Pendidikan 4.0. Dalam banyak kasus, akan perlu untuk mendidik dan melatih kembali karyawan perusahaan saat ini. Karena pendidikan dan pengetahuan mereka mungkin tidak cukup untuk kebutuhan masa depan perusahaan. Saat ini kurangnya karyawan yang memenuhi syarat adalah salah satu risiko tertinggi untuk Industri 4.0. Karena alasan ini tren teknologi baru (lingkungan belajar virtual, pembelajaran pabrik atau augmented reality) harus dimasukkan dalam pendidikan (Motyl et al., 2017).

Sejumlah karya meneliti cara untuk mengubah pendidikan itu sendiri sesuai dengan prinsip Industri 4.0, sementara secara bersamaan sebagian merekomendasikan untuk lebih pada transformasi pendidikan tinggi dengan menyesuaikan dengan visi Industri 4.0 dan sejumlah langkah untuk menjadikan pengalaman pendidikan siswa sebagai pengalaman individual yang dibutuhkan di dunia industri. Coşkun et al., (2019) melaporkan tentang penerimaan teknologi pendidikan digital terutama dalam pendidikan kejuruan. Mereka menekankan peran media digital sebagai sarana untuk individualisasi pendidikan dengan cara yang mirip Industri 4.0. Mereka menciptakan model variabel kondisi untuk pendidikan 4.0, yang terdiri dari perubahan teknologi dan proses, perubahan pengajaran dan pembelajaran, perubahan minat dan model ekonomi, dan wacana sosial-profesional. Mesin cerdas, 
komunikasi mesin ke mesin (M2M), keamanan data, big data, sistem pendukung seperti sistem realitas campuran adalah bidang yang mereka tekankan dalam mengubah teknologi. Dalam mengubah pengajaran dan pembelajaran, mereka mempertimbangkan individualisasi pembelajaran, pembelajaran sesuai permintaan, pembelajaran cloud, dan lingkungan belajar yang inovatif seperti simulasi realitas campuran, augmented reality, dan laboratorium jarak jauh.

Tenberg \& Pittich (2017) membahas dan menganalisis dampak industri 4.0 terutama pada pendidikan kejuruan. Mereka sampai pada kesimpulan yang menarik bahwa adopsi industri 4.0 dapat mengakibatkan penurunan pangsa pendidikan kejuruan demi pendidikan tinggi jika langkah-langkah yang diperlukan tidak diambil untuk mengubah pendidikan kejuruan secara mendasar. Dalam konteks pekerjaan kami, ini dapat ditafsirkan dengan cara bahwa pendidikan teknik di industri 4.0 tidak dapat dibayangkan tanpa kaitannya dengan praktik dan pekerjaan langsung, karena ada risiko kurangnya sumber dukungan teknis yang memadai. dari pendidikan kejuruan.

Di sisi yang lain dengan format industri 4.0 yang tengan bergulir, organisasi bisnis saat ini pun harus melakukan transformasi dan penyesuaian. Khususnya penyesuaian kompetensi personalia. Sejumlah penelitian menyebutkan, pengaruh industri 4.0 dalam dunia pekerjaan telah merubah struktur pekerjaan (Schumacher et al., 2016; Sorko et al., 2016; Samaranayake \& Takemura,2017).

Sejumlah penelitian yang telah dilakukan terkait dengan kompetensi SDM di industri 4.0 antara lain dilihat dari sisi supply (pendidikan), dilakukan oleh Hartanto et al., (2019), Sitepu et al., (2020), (Rofiki, 2019) dan sedangkan dari sisi demand (organisasi bisnis dan nonbisnis) penelitian terkait dengan kompetensi SDM personalia sudah dilaksanakan oleh Febriandono et al., (2019), Toto et al., (2019), Caressa (2019) dan lain-lain.

Penelitian yang dilakukan Sari et al. (2020) merumuskan bahwa diantara banyak faktor penting yang mempengaruhi kesiapan menyongsong industry 4.0 adalah faktor new media literacy, cross cultural competency, adaptive thinking dan virtual collaboration. Selanjutnya penelitian yang dilakukan Sitepu et al. (2020) mengemukakan bahwa terdapat faktor lain yang juga cukup penting dalam mempengaruhi kesiapan sumber daya manusia memasuki industri 4.0 yakni kecerdasan social (social intelligence). Kecerdasan sosial ini antara lain meliputi; mampu membaca situasi, menunjukkan rasa percaya diri, prilaku jujur dan tulus, bertutur kata jelas dan sopan serta mampu merasakan apa yang dirasakan orang lain (ada rasa empati).

Berdasarkan latar belakang, masih terlihat gap, dimana masih sangat mimim penelitian yang menelaah kompetensi SDM dengan pendekatan struktural dan menggunakan variabelvariabel pengamatan yang lebih kompleks. Secara khusus penelitian ini menindaklanjuti hasil temuan Sitepu et al. (2020) yang menguji 10 elemen kompetensi industri 4.0. Selanjutnya model tersebut oleh Sari et al. (2020) dan digunakan untuk menganalisis kompetensi personalia eksisting di sisi organisasi bisnis.

Peneliti menganggap analisis ini sangat penting bagi dunia perguruan tinggi untuk mengantisipasi dan mencermati perkembangan industri yang saat ini berorientasi pada industri 4.0. Penyesuaian gap kebutuhan industri dan ketersediaan SDM eksisting perlu dijawab dengan memperbaiki kehandalan kompetensi SDM yang telah dimiliki. Oleh karenanya melalui penelitian ini, peneliti ingin menganalisis lebih jauh bagaimana kompetensi yang dimiliki SDM perguruan tinggi dalam menghadapi industri 4.0 yang saat ini tengah bergulir. 


\section{Landasan Teori}

Untuk pertama kali, gagasan tentang Industri 4.0 dikemukakan pada catatan yang dipublis oleh Pemerintah Jerman (bulan November tahun 2011). Gagasan tersebut berkaitan dengan strategi teknologi tinggi yang akan diterapkan mulai tahun 2020. Dimana tahapan perkembangan industri dijelaskan dimulai dari; mekanisasi, elektrifikasi dan informasi, dan pada tahap ke empat diberi nama "Industri 4.0" (Zhou et al., 2015).

Berdasarkan pendapat Dujin et al. (2014); Lasi et al. (2014), sepanjang sejarah ada empat besar fase revolusi industri, 1,0;2,0;3,0 dan 4,0. Revolusi industri 1.0 juga dikenal dengan awal revolusi industri, diestimasi berlangsung pada tahun 1750-1850. Saat itu di dunia sedang reformasi besar pada bidang teknologi, manufaktur, pertambangan, transportasi dan pertanian serta memiliki pengaruh signifkan pada aspek budaya, ekonomi dan sosial masyarakat dunia. Revolusi industri 1.0 telah melahirkan sebuah sejarah, dimana mesin telah menggeser tenaga manusia demikian pula tenaga hewan. Kehadiran mesin uap di abad ke-18 adalah salah satu contohnya. Pada masa ini sejarah mencatat bahwa Industri 1.0 berhasil meningkatkan perekonomian secara dramatis, paling tidak telah terjadi peningkatan pendapatan perkapita rata-rata sejumlah negara sebesar 6 kali lipat dari sebelumnya.

Revolusi industri 2.0, dikenal sebagai fase perubahan teknologi yang pesat di sektor industri. Revolusi “industri 2.0" berlangsung pada 1870 - 1914 (awal Perang Dunia I). Ditandai dengan munculnya pembakaran combustion chamber, pembangkit listrik dan motor, telepon, mobil, pesawat dan lain-lain adalah ciri revolusi "industri 2.0".

Revolusi "industri 3.0" hadir ditandai dengan hadirnya teknologi digital dan internet. Pada fase ini ruang dan waktu terkompresi sedemikian rupa, ruang dan waktu tidak lagi berjarak. Revolusi industri 3.0 juga dikenal dengan revolusi digital. Era teknologi digital mengedepankan sisi waktu saat ini (real time) dan mengubah pola hubungan dan komunikasi masyarakat. Teknologi mendorong pabrik-pabrik cenderung memilih penggunaan mesin industri ketimbang menggunakan tenaga manusia. Sehingga mengakibatkan pereduksian tenaga manusia menjadi tidak terhindarkan, karena mesin lebih cepat dan lebih stabil dan tidak mengeluh.

Lebih lanjut pada "revolusi industri 4.0", ditemukan pola yang baru seiring dengan kehadiran disruptif teknologi. Pada era "industri 4.0", skala besar-kecil perusahaan tidak memberikan jaminan sukses atau tidaknya bisnis. Kunci keberhasilan bisnis adalah kelincahan organisasi untuk berprestasi secara cepat. Seperti yang dicontohkan oleh Uber dan Airbnb yang mengintimidasi pelaku besar sektor industri di dunia. Industri 4.0 menggambarkan konsep saat ini sebagai sebuah konsep kolektif.

Menurut Kemendikbud (2017) revolusi industri diartikan sebagai "perubahan yang sangat cepat, sedangkan industri adalah usaha proses produksi menghasilkan produk ataupun jasa". Sehingga revolusi industri dapat diartikan sebagai perubahan yang berlangsung sangat cepat dalam proses produksi, dimana awalnya kegiatan produksi dikerjakan manusia kemudian mulai digantikan mesin dan barang yang diproduksi ditingkatkan value added komersialnya. Revolusi industri telah mengganti cara kerja lama, dari yang sifatnya manual menuju digitalisasi dan otomatis.

Menurut Suwardana (2018) kunci eksistensi dari perubahan itu sendiri adalah inovasi. Inovasi menjadi faktor terpenting dalam mendeterminasi daya saing. "Capaian inovasi ditentukan sejauh mana suatu organisasi bisnis dapat mengoptimalkan body of knowledge, technology transfer, business incubation, science dan technopark". Sedangkan Lucke et al., (2008) mengemukakan komponen penting dari industri 4.0 antara lain; 1) smart factory, 2) sistem cyber-fisik, 3) self organisasi, 4) sistem baru dalam penjualan dan pengadaan, 5) sistem baru dalam produk dan development service, 6) adaptasi ke manusia, 7) tanggung 
jawab sosial perusahaan. Model yang lebih lengkap dikemukakan Sitepu et al. (2020), bahwa dalam menghadapi industri 4.0 dibutuhkan setidaknya 10 kompetensi antara lain; "sensemaking, social intelligence, novel dan adaptive thinking, cross-cultural competency, computational thinking, new-media literacy, transdisciplinary, design mindset, cognitive load management dan virtual collaboration".

Terdapat lima unsur penting yang akan diimplementasikan pemerintah dalam rangka menstimulus economic growth dan competitiveness bangsa di industri 4.0, antara lain: 1) melaksanakan sistem pembelajaran inovatif; 2) meninjau kebijakan kelembagaan PT agar lebih adaptif serta responsif; 3) peningkatan kualitas SDM dosen, peneliti dan perekayasa; 4) inovasi riset yang mendukung industri 4.0; serta 5) inovasi dan penguatan sistem dalam rangka peningkatan output industri dan mendorong lahirnya start up berbasis teknologi (Wisnubro, 2018).

Dalam artikel ilmiahnya Rüßmann et al. (2015) mengemukakan, setidaknya terdapat 9 pilar industri 4.0 antara lain, dikemukakan sebagai berikut: big-data dan analytics, robot autonomous, simulasi, integrasi horizontal dan vertical, the industrial internet of things, keamanan cyber, the cloud, manufaktur yang aditif, serta augmented reality. Sanders et all. (2016) menunjukkan enam prinsip desain, yang berasal dari teknologi Industri 4.0, yang mendukung perusahaan dalam mengidentifikasi proyek percontohan yang mungkin: 1) interoperabilitas, 2) virtualisasi, 3) desentralisasi, 4) kapabilitas real-time, 5) orientasi layanan dan 6) modularitas. Meskipun ketenaran berkembang, berbagai perusahaan masih berjuang untuk memahami gagasan keseluruhan Industri 4.0 dan konsep-konsep dan prinsipprinsip tertentu yang ada didalamnya.

Literasi media adalah keterampilan efektif dan efesien dalam menggunakan komunikasi masal (Strasburger \& Wilson, 2002). Ahli lain Potter (2005) dalam Poerwaningtias et al. (2013) mengartikan literasi media sebagai kemampuan menafsirkan pesan yang diterima dan cara mengantisipasinya. Livingstone (2004) mengemukakan dalam menunjang literasi diperlukan berbagai keahlian mulai awal hingga akhir proses. Penelitiannya mengidentifikasi beberapa masalah luar biasa untuk literasi media baru yang penting bagi kebijakan mempromosikan literasi media di antara populasi. Hasilnya adalah untuk memperluas pemahaman kita tentang literasi media sehingga mencakup hubungan yang terkondisikan secara historis dan budaya di antara tiga proses: (i) representasi simbolis dan material dari pengetahuan, budaya dan nilai-nilai; (ii) difusi keterampilan dan kemampuan interpretatif melintasi populasi (bertingkat); dan (iii) kelembagaan, khususnya, manajemen negara atas kekuatan yang akses ke dan penggunaan pengetahuan yang terampil membawa kepada mereka yang 'melek'. Chen, Lin, Li, \& Lee (2018) menyebutkan bahwa indikator new media literasi antara lain; functional consuming literacy, critical consuming literacy, functional presuming literacy dan critical presuming literacy, yang terdiri dari aspek participation dan creation.

Kompetensi lintas budaya dalam hal ini sebagai kemampuan individu yang berkontribusi pada efektivitas antar budaya terlepas dari persimpangan budaya tertentu. Meskipun beberapa aspek kognisi, perilaku, atau pengaruh mungkin sangat relevan di negara atau wilayah tertentu, bukti menunjukkan bahwa serangkaian kompetensi inti memungkinkan adaptasi terhadap budaya apa pun (Wiseman \& Jolene, 1993). Kompetensi lintas budaya bukanlah tujuan itu sendiri, tetapi merupakan serangkaian variabel yang berkontribusi terhadap efektivitas antar budaya. Hasil penelitian menunjukkan bahwa cross cultural competency sangat diperlukan dalam banyak hal, khususnya di dunia kerja (Leiba-O'sullivan, 1999); Daraiseh, 2018; Barzykowski et al. 2019; dan Perez et al. 2019); mengemukakan dimensi-dimensi cross cultural competency antara lain meliputi; emotional stability (stabilitas emosional), extraversion (kenyamanan berinteraksi dengan orang lain), agreeableness, 
openness to experience (keterbukaan pada pengalaman baru), conscientiousnes (pertimbangan hati nurani).

Dalam dunia kerja bentuk-bentuk umum kolaborasi secara virtual antara lain, virtual team, virtual learning-distance education, virtual meeting (Chen, Volk, \& Lin, 2004). Sejumlah penelitian terpopuler telah dilakukan terkait dengan virtual collaboration antara lain dilakukan oleh; Rennstich (2019); Srivastava \& Chandra (2018); Zhang et al. (2018) dan Beavers et al. (2017). Menurut Rennstich (2019) proses kreatif kolaboratif daring terdiri dari semua kegiatan yang bertujuan untuk menyelesaikan masalah kelompok yang tidak memiliki solusi standar, yang dimediasi melalui alat berbasis web. Biasanya, masalah seperti itu membutuhkan interdisipliner, pemikiran lateral, empati sosial dan ide yang luas dengan tujuan saling inspirasi. Proses yang diterapkan seringkali nonlinier dan bergantung pada cara multimoda komunikasi sinkron dan asinkron, dengan fokus khusus pada alat visual. Kolaborasi virtual adalah kegiatan yang berkaitan dengan penggunaan ekstensif saluran teknologi bagi anggota tim untuk saling bekerja sama dalam penyelesaian tugas proyek (Zhang et al. 2018) dan Peters \& Manz (2007).

Menurut Rahim et al. (2017) kecerdasan sosial meliputi; “a) empati, (b) penyelarasan, c) ketepatan empatik, d) pengertian sosial, e) sinkronisai, f) presentasi, g) pengaruh, dan h) kepedulian”. Sari et al., (2020) dan (Sitepu et al., 2020) dalam penelitiannya mengemukakan bahwa dengan menggunakan pendekatan confirmatory factor analysis bahwa social intelligence memiliki pengaruh terhadap kesiapan sumber daya manusia di industri 4.0.

Tortorella \& Fettermann (2018) menguji hubungan antara lean production (LP) dan penerapan industri 4.0 di perusahaan manufaktur Brasil. Temuan memperlihatkan bahwa praktik LP terkait secara positif dengan teknologi industri 4.0 dan penerapan bersamaan mereka mengarah pada peningkatan kinerja yang lebih besar. Selanjutnya, variabel kontekstual yang diselidiki memang penting bagi asosiasi ini, meskipun tidak semua aspek penting pada tingkat dan efek yang sama. Anwar, et al. (2018) mengemukakan bahwa pembentukan karakter mutlak diperlukan.

Motyl et al. (2017) menyoroti beberapa aspek tentang prilaku digital siswa dan pertimbangan siswa tentang kerangka kerja industri 4.0. Secara khusus, data yang menggambarkan hubungan siswa dengan perangkat digital dan tingkat pengetahuan mereka tentang beberapa topik tertentu seperti virtual, augmented dan realitas campuran, pencetakan 3D dan smart factory sangat signifikan dalam memahami apa yang dipikirkan siswa. Coşkun et al. (2019) dalam karyanya memperkenalkan peta jalan yang terdiri dari tiga pilar yang menggambarkan perubahan / peningkatan yang akan dilakukan di bidang pengembangan kurikulum, konsep laboratorium, dan kegiatan klub siswa terkait dengan kompetensi di industri 4.0. Benešová \& Tupa, (2017) menyatakan visi industri 4.0 tidak hanya akan membawa pendekatan baru tetapi juga metodologi dan teknologi, yang harus dilakukan diperkenalkan ke perusahaan. Transisi ke produksi yang sedemikian canggih tidak akan mungkin terjadi dengan segera. Alasannya adalah biaya keuangan yang tinggi dan kurangnya karyawan yang berkualitas.

Pfeiffer (2015) menguraikan kompetensi spesifik dan persyaratan kualifikasi dalam kaitannya dengan empat dimensi yang relevan dengan kualifikasi industri 4.0, dan, terakhir, menggunakannya untuk membuat rekomendasi untuk pembuat kebijakan, perusahaan dan mitra sosial. Benesova, Hirman, Steiner, \& Tupa (2018) dalam penelitiannya memfokuskan pada persyaratan pendidikan untuk pembuatan elektronik dalam konsep industri 4.0. Visi utama konsep yakni pabrik-pabrik pintar yang akan terhubung oleh sistem fisik-cyber. Pabrik-pabrik ini juga akan menggunakan teknologi baru seperti augmented reality. Keterampilan dan kualifikasi karyawan menjadi amat penting karena pengendalian atau 
pemeliharaan hanya akan membutuhkan karyawan dengan kualifikasi tinggi. The Education 4.0 adalah konsep baru pendidikan yang akan menggabungkan dunia nyata dan virtual.

Sitepu et al. (2020) dalam penelitiannya mengemukakan hasil analisis dengan menggunakan metode SEM diperoleh hasil bahwa, terdapat 8 variabel yang positif dan signifikan mempengaruhi kesiapan sumber daya manusia industri 4.0. Sedangkan dua variabel yang tidak signifikan adalah new media literacy dan design thinking.

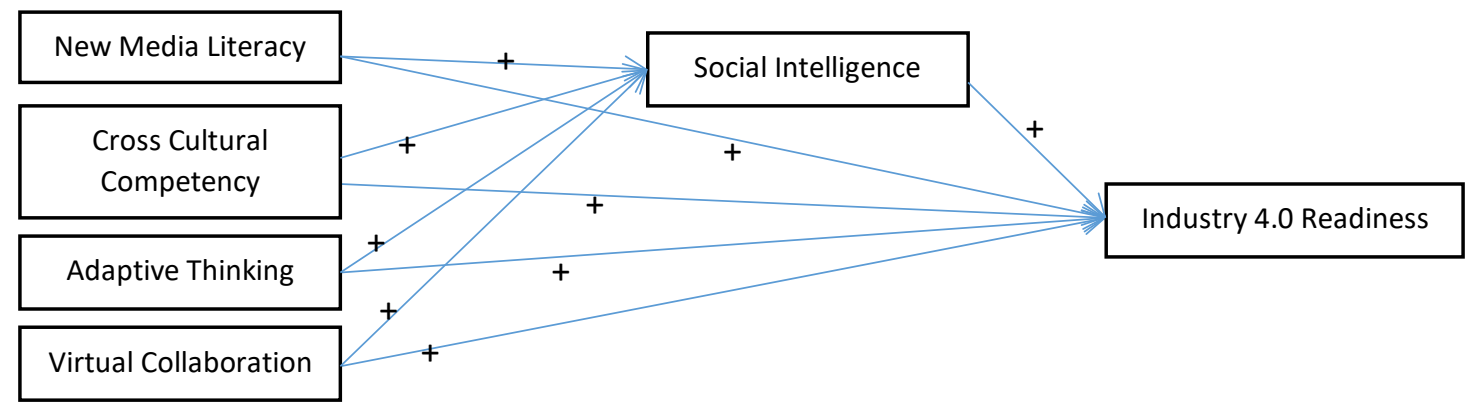

Gambar 1. Model Penelitian dan Hipotesis Penelitian

\section{Metode Penelitian}

Kegiatan riset ini dilakukan di Kota Medan dengan pengambilan responden dilakukan di beberapa institusi pendidikan tinggi vokasi negeri dan swasta. Untuk institusi polteknik negeri, data responden diambil antara lain di Politeknik Negeri Medan, Politeknik Pariwisata Negeri Medan, Politeknik Media Kreatif, dan Politeknik Teknologi Kimia Industri serta Poltekes. Sedangkan untuk politeknik swasta sampel di ambil di politeknik MBP, LP3I, LP3M, Ganesha dan IT\&B. Populasi penelitian ini adalah seluruh mahasiswa vokasi / politeknik baik yang ada di Kota Medan. Namun mengingat keterbatasan sumber daya yang ada populasi penelitian dibatasi pada mahasiswa aktif tingkat akhir di masing-masing kampus politeknik.

Adapun jumlah sampel yang diambil adalah 400 sampel yang diambil secara purposive random sampling. Responden diberikan kuesioner dengan pilihan jawaban menggunakan Skala Likert dengan skala 6; sangat setuju sekali (SSS) dengan skor 6, sangat setuju (SS) dengan skor 5, setuju (S) dengan skor 4, kurang setuju (KS) dengan skor 3, tidak setuju (TS) dengan skor 2 dan sangat tidak setuju (STS) dengan skor 1. Skala 6 ini digunakan agar responden tidak terperangkap dalam jawaban ragu-ragu seperti ketika yang digunakan dengan skala 5 .

Setelah diidentifikasi dan diklasifikasi, maka variabel-variabel penelitian didefinisikan secara operasional (Suryabrata, 2008). Adapun definisi operasional variabel penelitian, merujuk pada penelitian Yusnaini (2019), Sitepu et al. (2020), Febriandono et al. (2019) dikemukakan sebagai berikut:

a) New-media literacy (NML) adalah melek media baru yang dewasa ini berkembang. Indikator new media literacy antara lain; a) functional consuming literacy, terdiri dari consuming skill dan understanding, b) critical consuming literacy, terdiri dari analysis, synthesis dan evaluation c) functional presuming literacy yang terdiri dari aspek presuming skill, distribution dan production dan d) critical presuming literacy, yang terdiri dari aspek participation dan creation.

b) Cross-cultural competency (CCL) adalah komptensi lintas budaya dengan dimensi, a) emotional stability (stabilitas emosional), b) extraversion (kenyamanan berinteraksi dengan orang lain), c) agreeableness, d) openness to experience (keterbukaan pada pengalaman baru), e) conscientiousnes (pertimbangan hati nurani). 
c) Adaptive thinking (ADT) adalah "satu penalaran yang mencakup kemampuan induksi dan deduksi, meliputi; a) kemampuan untuk menarik kesimpulan secara logis, b) memperkirakan jawaban, c) memberikan penjelasan mengenai konsep/ prosedur jawaban yang digunakan, serta d) menilai kebenarannya secara matematika".

d) Virtual collaboration (VIR) adalah bentuk-bentuk umum kolaborasi secara virtual antara lain, a) virtual team, b) virtual learning-distance education, c) virtual meeting.

e) Social inteligent (SOS) adalah persepsi terkait dengan kecerdasan intelijen mahasiswa yang meliputi; empati, penyelarasan, ketepatan empatik, pengertian sosial, sinkronisai, presentasi, pengaruh dan kepedulian.

f) Kesiapan memasuki industri 4.0. (RED) adalah perspektif responen dalam melihat kesiapan kompetensi yang dimilikinya untuk memasuki industri 4.0. Adapun indikator dari kesiapan ini adalah: a) kesiapan skill dan kompetensi yang dimiliki dan b) kesiapan mental.

Untuk proses analisis data digunakan analisis data dengan dua tahap, yang pertama adalah dengan menjalankan structural equation model (SEM) dengan model langsung tanpa variabel intervening. Selanjutnya pada model kedua digunakan SEM dengan variabel intervening. Adapun alat bantu dalam proses analisis data diguakan software AMOS 22.

\section{Pembahasan}

Hasil measurement model diperoleh bahwa, data yang digunakan telah memenuhi uji validitas dan reliabilitas. Hasil uji validitas diperoleh bahwa semua konstruk variabel memiliki nilai loading factor $>0,5$ sebagaimana tersaji pada Gambar 2. Adapun untuk nilai reliability test dilakukan dengan memastikan nilai average variance extract $(A V E)>0,5$ yang juga sudah terpenuhi. Demikian pula hasil model fit yang sudah terpenuhi ditandai dengan nilai GFI, CFI, TLI yang mendekati 1 sebagaimana tersaji pada Gambar 2 dan Gambar 3.

Analisis penelitian ini dilakukan dengan menggunakan dua model. Model yang pertama adalah model yang menganalisis pengaruh langsung dari variabel independent yang ada. Pada model pertama ini variabel bebas yang digunakan adalah variabel new media literacy $(N M L)$, cross cultural competency (CCL), adaptive thinking (ADT), virtual collaboration (VIR) dan social intelligence (SOS). Sedangkan variabel terikatnya adalah kesiapan memasuki industry 4.0 (RED). Output model pertama ini adalah sebagai berikut:

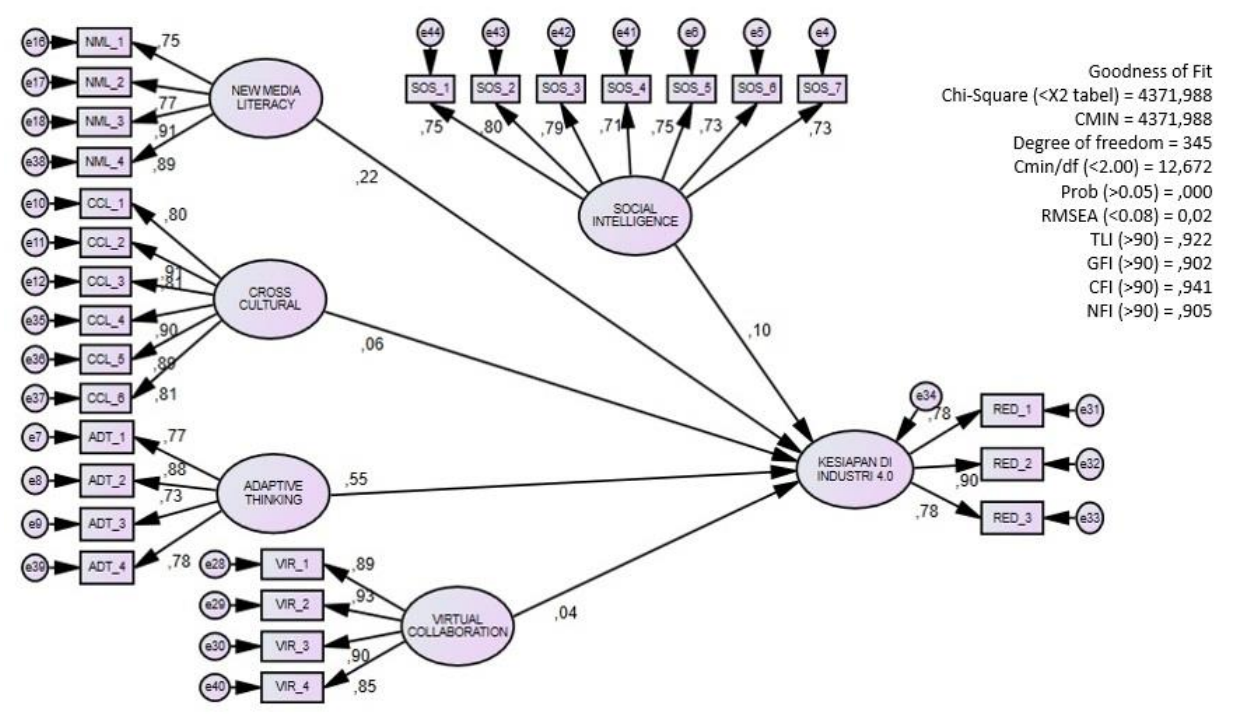

Gambar 2. Output Structural Equation Model ke-1 
Berdasarkan hasil output Structural Equation Model (SEM) ke-1 yang dilakukan dengan software AMOS 22 diperoleh hasil sebagaimana tersaji pada Gambar 1. Sesuai dengan output tersebut, diketahui bahwa dari sisi Goodness of Fit (GoF), model ini telah memenuhi kriteria GoF yang baik, hal ini ditandai dengan nilai Goodness of Fit Index (GFI), Tucker Lewis Index (TLI), Composite Fit Index (CFI) dengan nilai > 0,90 atau mendekati 1,0. Nilai GFI model ini adalah 0,902, nilai TLI 0,922, nilai CFI sebesar 0,941 dan nilai NFI sebesar 0,905. Pada model dapat dilihat pula bahwa nilai loading factor konstruk variabelvariabel yang digunakan memiliki nilai yang lebih besar dari 0,5 . Hal ini mengindikasikan bahwa semua indikator ataupun konstruk variabel telah memenuhi kriteria validitas dan reliabilitas. Selanjutnya juga diperoleh bahwa masing-masing variabel bebas memberikan pengaruh positif terhadap variabel terikat. Hal ini mengkonformasi teori yang dikemukakan pada beberapa penelitian sebelumnya, antara lain dikemukakan oleh Sitepu et al. (2020), Sari et al. (2020), Benešová and Tupa (2017) dan Karroubi et al. (2014). Adapun pengaruh masing-masing variabel disajikan pada Tabel 1 berikut:

Tabel 1. Regression Weight Model dengan Hubungan Langsung

\begin{tabular}{|c|c|c|c|c|c|c|c|}
\hline \multicolumn{3}{|c|}{ Variabel } & Estimate & S.E. & C.R. & $\mathrm{P}$ & Label \\
\hline $\begin{array}{l}\text { Industry } 4.0 \\
\text { Readiness }\end{array}$ & $<---$ & SOS & , 103 & ,048 & 2,144 & ,032 & Sig. \\
\hline $\begin{array}{l}\text { Industry } 4.0 \\
\text { Readiness }\end{array}$ & $<---$ & ADT &, 526 & ,049 & 10,661 & $* * *$ & Sig. \\
\hline $\begin{array}{l}\text { Industry } 4.0 \\
\text { Readiness }\end{array}$ & $<---$ & NML & ,209 & ,045 & 4,648 & $* * *$ & Sig. \\
\hline $\begin{array}{l}\text { Industry } 4.0 \\
\text { Readiness }\end{array}$ & $<---$ & CCL & ,052 & ,041 & 1,262 & ,207 & N.Sig. \\
\hline $\begin{array}{l}\text { Industry } 4.0 \\
\text { Readiness }\end{array}$ & $<---$ & VIR & ,033 & ,038 & ,854 & ,393 & N.Sig. \\
\hline
\end{tabular}

Sumber: Output Model 1

Berdasarkan Tabel 1 diketahui bawa terdapat tiga pengaruh langsung dari variabel yang digunakan signifikan dan dua pengaruh langsung yang tidak signifikan dalam mempengaruhi variabel terikat kesiapan memasuki indusri 4.0. Variabel yang memiliki pengaruh signifikan secara statistik antara lain social intelligence (SOS), adaptive thinking $(A D T)$ dan new media literacy $(N M L)$. Sedangkan variabel yang pengaruhnya tidak signifikan adalah cross cultural competency (CCL) dan virtual collaborations (VIR).

Selanjutnya modifikasi model dilakukan pada model kedua. Pada model kedua variabel social intelligence (SOS) dijadikan variabel intervening, dengan mengacu pada penelitian terdahulu yang dilakukan oleh Sitepu et al. (2020). Diduga dengan digunakannya variabel social intelligence ini sebagai intervening variabel model penelitian akan lebih variatif dan lebih baik. Diharapkan pula terjadi peningkatan nilai Goodness of Fit dan signifikasi variabel-variabel yang digunakan dalam mempengaruhi variabel terikat kesiapan memasuki indusri 4.0. Hasil output model kedua selanjutnya ditampilkan pada gambar berikut ini: 


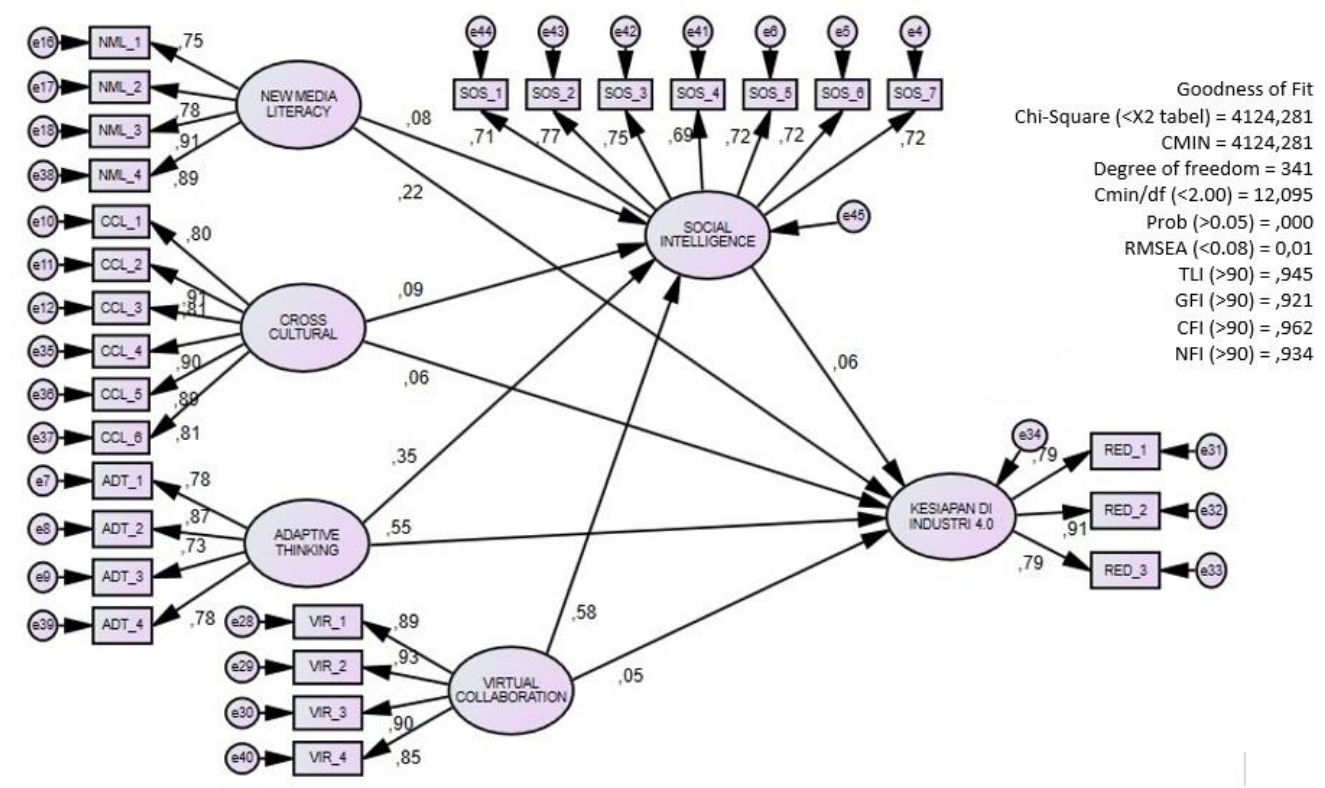

Gambar 3 Output Structural Equation Model (SEM)

Berdasarkan hasil output structural equation model (SEM) kedua ini diketahui bahwa dari sisi Goodness of Fit (GoF), model ini telah memenuhi kriteria GoF yang lebih baik, hal ini ditandai dengan nilai Goodness of Fit Index (GFI), Tucker Lewis Index (TLI), Composite Fit Index (CFI) dengan nilai > 0,90 atau mendekati 1,0. Nilai GFI model ini adalah 0,921, nilai TLI 0,945, nilai CFI sebesar 0,962 dan nilai NFI sebesar 0,934 dimana nilai-nilai ini lebih tinggi dari nilai yang diperoleh pada model pertama. Sementara untuk konstruk variabel yang digunakan masih tetap sama dengan model sebelumnya dengan nilai loading factor yang lebih besar dari 0,5. Untuk hubungan-hubungan variabel menjadi lebih kompleks pada model kedua ini, dimana hasil regression weight model dengan variabel intervening ini disajikan pada Tabel 2.

Tabel 2. Regression Weight Model dengan Variabel Intervening

\begin{tabular}{|c|c|c|c|c|c|c|c|}
\hline & & & Estimate & S.E. & C.R. & $\mathrm{P}$ & Label \\
\hline Social Intelligence (SOS) & $<--$ & NML & ,072 & ,038 & 1,889 & ,050 & Sig. \\
\hline Social Intelligence (SOS) & $<---$ & VIR & ,447 & 041 & 10,989 & $* * *$ & Sig. \\
\hline Social Intelligence (SOS) & $<--$ & ADT & ,310 & ,043 & 7,144 & $* * *$ & Sig. \\
\hline Social Intelligence (SOS) & $<---$ & $\mathrm{CCL}$ & 074 & ,036 & 2,061 & ,039, & Sig. \\
\hline $\begin{array}{l}\text { Readiness on Industry } 4.0 \\
\text { (RED) }\end{array}$ & $<--$ & SOS & ,061 &, 076 & 3,803 &, 022 & Sig. \\
\hline $\begin{array}{l}\text { Readiness on Industry } 4.0 \\
\text { (RED) }\end{array}$ & $<--$ & ADT &, 540 &, 056 & 9,582 & $* * *$ & Sig. \\
\hline $\begin{array}{l}\text { Readiness on Industry } 4.0 \\
\text { (RED) }\end{array}$ & $<---$ & NML & ,211 &, 045 & 4,644 & $* * *$ & Sig. \\
\hline $\begin{array}{l}\text { Readiness on Industry } 4.0 \\
\text { (RED) }\end{array}$ & $<--$ & CCL &, 050 &, 042 & 2,203 & ,029 & Sig. \\
\hline $\begin{array}{l}\text { Readiness on Industry } 4.0 \\
\text { (RED) }\end{array}$ & $<--$ & VIR & ,046 &, 053 & ,870 & ,384 & N.Sig \\
\hline
\end{tabular}

Sumber: Output Model 2 
Sesuai dengan hasil output regression weight model dengan variabel intervening pada model kedua, diperoleh bahwa, semua hubungan variabel eksogen dan endogen adalah positif dan signifikan mempengaruhi variabel terikat kesiapan pada industri 4.0 kecuali untuk pengaruh variabel virtual collaboration (VIR) yang tidak signifikan dalam mempengaruhi variabel terikat kesiapan pada industri 4.0. Hasil ini mengindikasikan bahwa model ini juga cukup baik sebagai estimator variabel kesiapan memasuki industri 4.0 bahkan mengkonfirmasi hasil termuan pada model pertama dengan hubungan langsung semua variabel eksogen dan endogen.

Untuk pengaruh langsung variabel bebas terhadap variabel terikat diperoleh bahwa variabel tertinggi yang mempengaruhi social intelligent (SOS) adalah virtual collaboration (VIR) sebesar 0,576 diikuti adaptive thinking (ADT) sebesar 0,348 dan variabel cross cultural competency $(C C L)$ sebesar 0,89 .

Tabel 3. Standardized Direct Effect

\begin{tabular}{|l|cccccc|}
\hline Variabel & VIR & NML & CCL & ADT & SOS & RED \\
\hline Social Intelligence (SOS) &, 576 &, 083 &, 089 &, 348 &, 000 &, 000 \\
Readiness on Industry 4.0 (RED) &, 054 &, 221 &, 055 &, 552 &, 056 &, 000 \\
\hline
\end{tabular}

Sumber: Data Penelitian Diolah

Untuk pengaruh tidak langsung variabel bebas terhadap variabel terikat melalui variabel social intelligent (SOS) diperoleh bahwa varibel tertinggi yang mempengaruhi readiness to industry $4.0(R E D)$ adalah virtual collaboration (VIR) sebesar 0,032 diikuti adaptive thinking $(A D T)$ sebesar 0,019 dan variabel cross cultural competency $(C C L)$ sebesar 0,005 serta serta new media literacy $(N M L)$ sebesar 0,005 .

Tabel 4 Standardized Indirect Effect

\begin{tabular}{|l|cccccc|}
\hline & VIR & NML & CCL & ADT & SOS & RED \\
\hline Social Intelligence (SOS) &, 000 &, 000 &, 000 &, 000 &, 000 &, 000 \\
Readiness on Industry 4.0 (RED) &, 032 &, 005 &, 005 &, 019 &, 000 &, 000 \\
\hline
\end{tabular}

Sumber: Data Penelitian Diolah

Untuk pengaruh total variabel bebas terhadap variabel terikat readiness to industry 4.0 (RED) diperoleh bahwa variabel memberikan pengaruh paling tinggi yakni adaptive thinking (ADT) sebesar 0,571 diikuti new media literacy (NML) sebesar 0,226 dan vritual collaboration (VIR) sebesar 0,86 . Sedangkan untuk pengaruh total variabel bebas terhadap variabel terikat social intelligent (SOS) diperoleh bawah pengaruh terbesar dari virtual collaboration (VIR) sebesar 0,576 dan adaptive thinking (ADT) sebesar 0,348.

Tabel 5. Standardized Total Effect

\begin{tabular}{|l|cccccc|}
\hline & VIR & NML & CCL & ADT & SOS & RED \\
\hline Social Intelligence (SOS) &, 576 &, 083 &, 089 &, 348 &, 000 &, 000 \\
Readiness on Industry 4.0 (RED) &, 086 &, 226 &, 060 &, 571 &, 056 &, 000 \\
\hline
\end{tabular}

Sumber: Data Penelitian Diolah 
Selanjutnya dilakukan analisis jenis peran mediasi variabel intervening yang digunakan. Penentuan peran mediasi variabel intervening dapat dilakukan dengan membandingkan output model tanpa variabel intervening dengan model yang menggunakan variabel intervening. Adapun kriteria penetapan jenis peran mediasi adalah; bereperan mediation effect, bila pengaruh langsung tidak signifikan dan pengaruh tidak langsung signfikan. Berperan partial mediation effect manakala pengaruh langsung signifikan dan pengaruh tidak langsung juga signifikan. Sedangkan peran no mediation effect terjadi bila tidak ada pengaruh baik secara langsung maupun tidak langsung secara signifikan.

Tabel 6. Penentuan Jenis Variabel Moderasi

\begin{tabular}{|l|l|l|l|}
\hline No & \multicolumn{1}{|c|}{ Model Tidak Langsung } & \multicolumn{1}{c|}{ Model Langsung } & \multicolumn{1}{c|}{ Kriteria } \\
\hline 1 & $\begin{array}{l}\text { Pengaruh NML terhadap SOS } \\
\text { signifkan dan pengaruh SOS } \\
\text { terhadap RED juga signifikan. }\end{array}$ & $\begin{array}{l}\text { Pengaruh NML } \\
\text { terhadap RED } \\
\text { signifikan }\end{array}$ & $\begin{array}{l}\text { SOS memiliki peran } \\
\text { Partial Mediation Effect } \\
\text { untuk variabel NML }\end{array}$ \\
\hline 2 & $\begin{array}{l}\text { Pengaruh VIR terhadap SOS } \\
\text { signifkan dan pengaruh SOS } \\
\text { terhadap RED juga signifikan. }\end{array}$ & $\begin{array}{l}\text { Pengaruh VIR } \\
\text { terhadap RED tidak } \\
\text { signifikan }\end{array}$ & $\begin{array}{l}\text { SOS memiliki peran Full } \\
\text { Mediation Effect untuk } \\
\text { variabel VIR }\end{array}$ \\
\hline 3 & $\begin{array}{l}\text { Pengaruh ADT terhadap SOS } \\
\text { signifkan dan pengaruh SOS } \\
\text { terhadap RED juga signifikan. }\end{array}$ & $\begin{array}{l}\text { Pengaruh ADT } \\
\text { terhadap RED } \\
\text { signifikan }\end{array}$ & $\begin{array}{l}\text { SOS memiliki peran } \\
\text { Partial Mediation Effect } \\
\text { untuk variabel ADT }\end{array}$ \\
\hline 4 & $\begin{array}{l}\text { Pengaruh CCL terhadap SOS } \\
\text { signifkan dan pengaruh SOS } \\
\text { terhadap RED juga signifikan }\end{array}$ & $\begin{array}{l}\text { Pengaruh CCL } \\
\text { terhadap RED tidak } \\
\text { signifikan }\end{array}$ & $\begin{array}{l}\text { SOS memiliki peran Full } \\
\text { Mediation Effect untuk } \\
\text { variabel CCL }\end{array}$ \\
\hline
\end{tabular}

Sumber: Data Penelitian Diolah

Berdasarkan hasil perbandingan output model, sebagaimana disajikan pada Tabel 6 , maka dapat disimpulkan, variabel social intelligence (SOS) memiliki peran partial mediation effect untuk variabel new media literacy (NML). Hal ini dapat dibuktikan dengan konsistensi signifikansi pengaruh variabel new media literacy $(N M L)$ baik dengan variabel intervening maupun tanpa variabel intervening social intelligence (SOS). Variabel social intelligence (SOS) memiliki peran full mediation effect untuk variabel virtual collaboration (VIR). Hal ini dapat dibuktikan dengan perbaikan nilai signifikansi model bila dengan menggunakan model dengan variabel intervening. Pada model hubungan langsung pengaruh pengaruh virual collaboration (VIR) terhadap readiness on dindustry 4.0 (RED) tidak signifikan. Sementara pada model dengan pengaruh tidak langsung, diperoleh bahawa pengaruh virtual collaboration (VIR) terhadap social intelligence (SOS) signifkan dan pengaruh social intelligence (SOS) terhadap readiness on dindustry 4.0 (RED) juga signifikan.

Variabel social intelligence (SOS) memiliki peran partial mediation effect untuk variabel adaptive thinking (ADT). Hal ini dapat dibuktikan dengan konsistensi signifikansi pengaruh variabel adaptive thinking (ADT) baik dengan variabel intervening maupun tanpa variabel intervening social intelligence (SOS). Variabel social intelligence (SOS) memiliki peran full mediation effect untuk variabel cross cultural competency (CCL). Hal ini dapat dibuktikan dengan perbaikan nilai signifikansi model bila dengan menggunakan model dengan variabel intervening. Pada model hubungan langsung pengaruh pengaruh cross cultural competency $(C C L)$ terhadap readiness on dindustry 4.0 (RED) tidak signifikan. Sementara pada model dengan pengaruh tidak langsung, diperoleh bahawa pengaruh cross 
cultural competency $(C C L)$ terhadap social intelligence (SOS) signifkan dan pengaruh social intelligence $(S O S)$ terhadap readiness on dindustry 4.0 (RED) juga signifikan.

\section{Kesimpulan dan Saran}

Hasil analisis data dengan full model SEM duperoleh bahwa new media literacy, virtual collaboration, adaptive thinking dan cross cultural competency berpengaruh positif dan signifikan terdahap variabel social intelligence. Sedangkan untuk variabel readiness on dindustry 4.0 secara positif dan signifikan dipengaruhi oleh variabel adaptive thinking, new media literacy, dan cross cultural competency. Sedangkan pengaruh variabel virtual collaboration adalah positif namun tidak signifikan.Untuk peran mediasi dapat disimpulkan bahwa variabel social intelligence memiliki peran partial mediation effect untuk variabel new media literacy dan adaptive thinking. Sedangkan untuk variabel virtual collaboration dan cross cultural competency terhadap variabel social intelligence memberikan peran full mediation effect.

Adapun saran yang direkomendasikan terkait dengan penelitian ini adalah pihak lembaga penyelenggara pendidikan tinggi, dalam upaya mendorong peningkatan kualitas sumber daya manusia, khususnya dalam mengantisipasi industri 4.0 agar dapat mempehatikan dan memaksimalkan aspek-aspek; social intelligence, adaptive thinking, cross cultural competency, new media literacy, transdisciplinary dan virtual collaboration. Bagi peneliti lain yang akan melanjutkan penelitian ini dengan tema yang sama diharapkan mampu mengembangkan model penelitian ini menjadi lebih kompleks seperti menambah variabel baru dan dilakukan pada objek yang berbeda dari penelitian terdahulu sehingga tercipta penelitian-penelitian lain yang lebih baik lagi ke depannya.

\section{Daftar Pustaka}

Annunziata, M., \& Evans, P. C. (2012). Industrial Internet: Pushing the Boundaries of Minds and Machines. General Electric.

Anwar, C., Saregar, A., Hasanah, U., \& Widayanti, W. (2018). The Effectiveness of Islamic Religious Education in the Universities: The Effects on the Students' Characters in the Era of Industry 4.0. Tadris: Jurnal Keguruan Dan Ilmu Tarbiyah, 3(1), 77.

Barzykowski, K., Majda, A., Przyłęcki, P., \& Szkup, M. (2019). The Cross-Cultural Competence Inventory: Validity and Psychometric Properties of the Polish Adaptation. PLOS ONE, 14(3), e0212730.

Beavers, S., Christopher, P. G., Cheryl, L., Margaret, K. S., \& John, P. K. (2017). Virtual Collaboration.

Benesova, A., Hirman, M., Steiner, F., \& Tupa, J. (2018). Analysis of Education Requirements for Electronics Manufacturing within Concept Industry 4.0. 2018 41st International Spring Seminar on Electronics Technology (ISSE), 1-5.

Benešová, A., \& Tupa, J. (2017). Requirements for Education and Qualification of People in Industry 4.0. Procedia Manufacturing, 11, 2195-2202.

Blanchet, M., Rinn, T., Von Thaden, G., \& De Thieulloy, G. (2014). Industry 4.0: The New Industrial Revolution-How Europe will Succeed. In Roland Berger Strategy Consultants $\mathrm{GmbH}$.

Caressa, S. R. (2019). Hubungan Kompetensi Era Industri 4.0, Beban Kerja Organisasional, Citizenship Behavior dan Kinerja Karyawan - Study of Employees of PDAM Sleman Regency. Jurnal Manajemen Universitas Teknologi Yogyakarta, 9(1). 
Chen, D.-T., Lin, T.-B., Li, J.-Y., \& Lee, L. (2018). Establishing The Norm of New Media Literacy of Singaporean Students: Implications to Policy and Pedagogy. Computers \& Education, 124, 1-13.

Chen, J. C. H., Volk, L., \& Lin, B. (2004). Virtual Collaboration in The Workplace. Academy of Management Perspectives, $V(1)$.

Coşkun, S., Kayıkcı, Y., Gençay, E., Coşkun, S., Kayıkcı, Y., \& Gençay, E. (2019). Adapting Engineering Education to Industry 4.0 Vision. Technologies, 7(1), 10.

Daraiseh, S. (2018). Intercultural Competence Among English Learners at Yarmouk University Jordan. 16(10), 503-514.

Dujin, A., Geissler, C., \& Horstkötter, D. (2014). Think Act Industry 4.0. The new industrial revolution: How Europe will succeed.

Febriandono, M. H., Mulia, F. H. N., \& Iswara, N. H. (2019). Pengaruh Kompetensi Personal terhadap Kesiapan Perubahan dalam Industri 4.0. Jurnal TAM (Technology Acceptance Model), 9(2), 107-115.

Hartanto, C. F. B., Rusdarti, \& Abdurrahman. (2019). Tantangan Pendidikan Vokasi di Era Revolusi Industri 4.0 dalam Menyiapkan Sumber Daya Manusia yang Unggul. Seminar Nasional Pascasarjana.

Karroubi, M., Hadinejad, A., \& Mahmoudzadeh, S. M. (2014). A Study on Relationship between Cultural Intelligence and Cross-cultural Adjustment in Tour Management. Management Science Letters, 4, 1233-1244.

Kemendikbud. (2017). Kamus Besar Bahasa Indonesi (KBBI) - Kamus Versi Online. KBBI Online.

Lasi, H., Fettke, P., Kemper, H.-G., Feld, T., \& Hoffmann, M. (2014). Industry 4.0. Business \& Information Systems Engineering, 6(4), 239-242.

Leiba-O'sullivan, S. (1999). The Distinction between Stable and Dynamic Cross-cultural Competencies: Implications for Expatriate Trainability. Journal of International Business Studies, 30(4), 709-725.

Livingstone, S. (2004). Media Literacy and the Challenge of New Information and Communication Technologies. The Communication Review, 7(1), 3-14.

Lucke, D., Constantinescu, C., \& Westkämper, E. (2008). Smart Factory - A Step towards the Next Generation of Manufacturing. In Manufacturing Systems and Technologies for the New Frontier (pp. 115-118). Springer London.

Motyl, B., Baronio, G., Uberti, S., Speranza, D., \& Filippi, S. (2017). How will Change the Future Engineers' Skills in the Industry 4.0 Framework? A Questionnaire Survey. Procedia Manufacturing, 11, 1501-1509.

Nurwardani, P. (2018). Strategi Pembelajaran Sains dan Teknologi di Perguruan Tinggi Mengawal Revolusi Industri 4.0. Orasi Ilmiah Unpar.

Perez, S. E., Watson, J. C., \& Scott Barnicle, I. I. (2019). Effects of Cross-cultural Communication Competence on Tennis Performance. Journal of Articles in Support of the Null Hypothesis, 15(2). www.jasnh.com

Peters, L. M., \& Manz, C. C. (2007). Identifying Antecedents of Virtual Team Collaboration. Team Performance Management: An International Journal, 13(3/4), 117-129.

Pfeiffer, S. (2015). Effects of Industry 4.0 on Vocational Education and Training. Voced Plus.

Poerwaningtias, I., Rianto, P., Ni'am, M., Adiputra, W. M., Marganingtyas, D., Mirasari, E., \& Misbah, N. A. (2013). Model-Model Gerakan Literasi Media dan Pemantauan Media di Indonesia (P. Rianto (ed.)). Pusat Kajian Media dan Budaya Populer.

Quint, F., Sebastian, K., \& Gorecky, D. (2015). A Mixed-reality Learning Environment. Procedia Computer Science, 75, 43-48. 
Rahim, M., Usman, I., \& Puluhulawa, M. (2017). Kecerdasan Sosial dan Prestasi Belajar Siswa (Tinjauan dari Perspektif Bimbingan dan Konseling Belajar ). Proceeding Seminar Dan Lokakarya Nasional Revitalisasi Laboratorium Dan Jurnal Ilmiah Dalam Implementasi Kurikulum Bimbingan Dan Konseling Berbasis KKNI.

Rennstich, J. K. (2019). Creative Online Collaboration: A Special Challenge for Co-creation. Education and Information Technologies, 24(2), 1835-1836.

Rofiki, M. (2019). Urgensi Supervisi Akademik dalam Pengembangan Profesionalisme Guru di Era Industri 4.0. Indonesian Journal Pf Basic Education, 2(3), 502-514.

Rüßmann, M., Lorenz, M., Gerbert, P., \& Waldner, M. (2015). Industry 4.0: The Future of Productivity and Growth in Manufacturing Industries. Boston Consulting Group, 9(1), 54-89.

Rüßmann, M., Lorenz, M., Gerbert, P., Waldner, M., Justus, J., Engel, P., \& Harnisch, M. (2015). Industry 4.0: The future of productivity and growth in manufacturing industries. Boston Consulting Group, 9.

Samaranayake, S. U., \& Takemura, T. (2017). Employee Readiness for Organizational Change: A Case Study in An Export Oriented Manufacturing Firm in Sri Lanka. Eurasian Journal of Business and Economics, 10(12), 1-16.

Sanders, A., Elangeswaran, C., \& Wulfsberg, J. (2016). Industry 4.0 Implies Lean Manufacturing: Research Activities in Industry 4.0 Function as Enablers for Lean Manufacturing. Journal of Industrial Engineering and Management, 9(3), 811.

Sari, D. C., Berutu, E. P., Pranoto, H., \& Sitepu, E. S. (2020). Readiness, Personal Competency Model, In Facing Industry 4.0. 4th Bogor International Conference for Social Science 2020 (4th BICSS 2020).

Schumacher, A., Erol, S., \& Sihn, W. (2016). A Maturity Model for Assessing Industry 4.0 Readiness and Maturity of Manufacturing Enterprises. Procedia CIRP, 52, 161-166.

Sitepu, E. S., Rangkuti, A. E., \& Fachrizal, F. (2020). Competency Analysis of Fresh Graduated Higher Education in Supporting Industrial Era 4.0. International Journal of Indonesian Education, 4(1), 82-101.

Sorko, S. R., Rabel, B., \& Richter, H. M. (2016). The Future of Employment - Challenges in Human Resources through Digitalization. International Scientific Journals Scientific Technical Union of Mechanical Engineering Industry-4.0, 1(2), 128-131.

Suryabrata, S. (2008). Metodologi Penelitian. PT Raja Grafindo Persada.

Tenberg, R., \& Pittich, D. (2017). Ausbildung 4.0 Oder Nur 1.2? Analyse Eines TechnischBetrieblichen Wandels Und Dessen Implikationen Für Die Technische Berufsausbildung. Journal of Technical Education (JOTED), 5(1).

Tortorella, G. L., \& Fettermann, D. (2018). Implementation of Industry 4.0 and lean production in Brazilian manufacturing companies. International Journal of Production Research, 56(8), 2975-2987.

Toto, Nursolih, E., Suhendi, R. M., \& Usmar, D. (2019). Faktor yang Menentukan Kebutuhan Sumber Daya Manusia di Era Industri 4.0. Jurnal Dan Prosiding Fakultas Ekonomi Dan Bisnis Unsoed, 9(1), 222-227.

Wiseman, R. L., \& Jolene, K. (1993). Handbook of International and Intercultural Communication - Google Books. Sage.

Wisnubro. (2018). Lima Elemen Penting Menjawab Tantangan Revolusi Industri 4.0JPP.go.id. JPP.

Yusnaini. (2019). Era Revolusi Industri 4.0: Tantangan dan Peluang dalam Upaya Meningkatkan Literasi Pendidikan. Prosiding Seminar Nasional Program Pasca Sarjana, 1073-1085. 
Zhang, Y., Sun, J., Yang, Z., \& Wang, Y. (2018). Mobile Social Media in InterOrganizational Projects: Aligning Tool, Task and Team for Virtual Collaboration Effectiveness. International Journal of Project Management, 36(8), 1096-1108.

Zhou, K., Taigang Liu, \& Lifeng Zhou. (2015). Industry 4.0: Towards Future Industrial Opportunities and Challenges. 2015 12th International Conference on Fuzzy Systems and Knowledge Discovery (FSKD), 2147-2152. 